\title{
THE INFLUENCE OF POLICY INTERVENTION, PERSONAL FACTOR, AND PHYSICAL ENVIRONMENTAL FACTOR ON PRO- ENVIRONMENTAL BEHAVIOR
}

\author{
Agustin Yolandari \\ agustiyolandari13@gmail,com \\ Aggota HIMPSI Provinsi Jawa Barat
}

\author{
Jahja Umar \\ umarindo@rad.net,id \\ Fakultas Psikologi UIN Syarif \\ Hidayatullah Jakarta
}

\begin{abstract}
Pro-environmental behavior is an act to protect and minimize the negative impacts of human activities on the environment. The purpose from this study is to determine whetherthere's influence from interventions policy, attitude towards pro-environmental behavior, subjective norm, perceived behavioral control (PBC), environmental knowledge (system knowledge, action related knowledge, and knowledge effectiveness), physical environmental factors (physical family environmental factor and physical society environmental factor), gender and age on pro-environmental behavior. The samples are 201 people who lives in Depok and South Tangerang, who has implemented an intervention policy called "Community-based Waste Management" and the areas of which the intervention policy have not been applied. The sampling technique used is a nonprobability sampling and the data analysis used is Multiple Regression Analysis on the level of significance at 0.05 . The results showed that there is a significant influence on the whole independent variable towards proenvironmental behavior $\left(R^{2}=40.1 \%\right)$. Minor hypothesis test results shows that there are 8 variables that have a significant influence on pro-environmental behavior which are interventions policy, subjective norm, perceived behavioral control $(P B C)$, system knowledge, physical family environmental factor, age and interaction between policy intervention and action related knowledge.
\end{abstract}

Keywords: Pro-Environmental Behavior, Interventions Policy, Attitude Towards Pro- Environmental Behavior, Subjective Norm, Perceived Behavioral Control (PBC), Environmental Knowledge, Physical Environmental Factors

\section{Abstrak}

Perilaku pro-lingkungan adalah perilaku yang dilakukan untuk melindungi, memperbaiki serta meminimalisir dampak negatif dari aktivitas manusia terhadap lingkungan. Tujuan dari penelitian ini adalah untuk mengetahui apakah ada pengaruh dari kebijakan intervensi, sikap terhadap perilaku pro-lingkungan, norma subjektif, Perceived Behavior Control (PBC), pengetahuan lingkungan (system knowledge, action related knowledge, knowledge effectiveness), faktor lingkungan fisik (faktor lingkungan fisik keluarga, faktor lingkungan fisik masyarakat), jenis kelamin dan usia terhadap perilaku pro-lingkungan. Sampel pada penelitian ini adalah masyarakat yang bertempat tinggal di Depok dan Tangerang Selatan yang telah diterapkan kebijakan intervensi "Pengelolaan Sampah Berbasis Masyarakat" dan daerah yang belum diterapkan, yaitu sebanyak 201 orang. Teknik pengambilan sampelyang digunakan adalah non-probability sampling. Analisis data yang digunakan dalam penelitian ini adalah Multiple Regression Analysis pada taraf signifikansi 0.05. Hasil penelitian ini menunjukkan bahwa ada pengaruh yang signifikan dari seluruh independent variable terhadap perilaku pro-lingkungan $\left(\mathrm{R}^{2}=40,1 \%\right)$. Hasil uji hipotesis minor menunjukkan variabel yang memiliki pengaruh yang signifikan terhadap perilaku pro-lingkungan ialah kebijakan intervensi, norma subjektif, Perceived Behavior Control (PBC), system knowledge, faktor lingkungan fisik keluarga, usia dan interaksi antara kebijakan intervensi dan action related knowledge

Kata Kunci: Perilaku Pro-Lingkungan, Kebijakan Intervensi, Sikap terhadap Perilaku ProLingkungan, Norma Subjektif, Perceived Behavior Control (PBC), Pengetahuan Lingkungan, Faktor Lingkungan Fisik. 


\section{PENDAHULUAN}

Perubahan iklim sebagai bukti nyata dari pemanasan global telah mengakibatkan ketidakstabilan atmosfer di lapisan bawah, terutama lapisan terdekat dengan permukaan bumi. Peningkatan pemanasan global saat ini terjadi akibat meningkatnya konsentrasi gas rumah kaca (GRK). Dalam jumlah tertentu GRK dibutuhkan untuk menjaga suhu ekstrim bumi agar tidak terlalu tinggi atau terlalu rendah, namun jika jumlah radiasi yang terperangkap oleh atmosfer bumi berlebihan, maka suhu atmosfer dan permukaan bumi akan semakin meningkat dan terjadilah pemanasan global yang salah satunya dapat menyebabkan terjadinya perubahan iklim (Susandi, 2008).

Menurut Scheneider (dalam Oskamp, 2000), pemanasan global yang terjadi akan mengakibatkan kandungan zat karbondioksida $\mathrm{CO}_{2}$ tercampur kedalam atmosfe bumi. Berdasarkan Intergovernmental Panel on Climate Change (IPCC) jumlah $\mathrm{CO}_{2}$ di atmosfer mengalami peningkatan yang drastis dan sudah mencapai level yang belum pernah terjadi sebelumnya dalam sejarah geologi. Jika hal ini terus berlanjut, IPCC memperkirakan hal ini akan menghasilkan rata-rata pemanasan suhu udara permukaan bumi sekitar 3 1/2 derajat Fahrenheit pada tahun 2100. Daerah-daerah kutub akan mengalami pemanasan yang lebih cepat dan mengakibatkan mencairnya kutub es secara meluas, sehingga dapat menaikkan tingkat laut dan menyebabkan bencana banjir besar-besaran pada dataran rendah daerah pesisir di banyaknegara.

Adapula masalah lingkungan lainnya yang menjadi isu nasional saat ini ialah masalah kebakaran hutan dan bencana asap, seperti yang terjadi di daerah Riau pada tahun 2015. Berdasarkan data dari Badan Nasional Penanggulangan Bencana (BNPB), luas areal kebakaran hutan dan lahan yang terjadi di Indonesia pada tahun 2015 mencapai 2.089.911 hektare (cnnindonesia, 2015).

Berdasarkan hasil riset yang dipublikasikan oleh Kementerian Lingkungan Hidup dan Kehutanan Republik Indonesia dalam Pengelola Lingkungan Hidup Daerah (BPLHD) DKI Jakarta menyatakan bahwa Indeks Kualitas Lingkungan Hidup (IKLH) Provinsi DKI Jakarta tahun 2015 berada dalam status waspada, dengan nilai 32,99 (BPLHD Provinsi DKI Jakarta, 2015). Hal ini mengindikasikan buruknya kualitas lingkungan hidup di kota Jakarta, baik itu disebabkan oleh kepadatan tingkat penduduk, maupun pola perilaku masyarakat yang tidak ramah lingkungan, seperti kebiasaan membuang sampah sembarang.

Dalam BPLHD Provinsi DKI Jakarta (2014) disebutkan bahwa kondisi lingkungan sangat dipengaruhi oleh aktivitas manusia baik dari segi kuantitas maupun kualitas. Jumlah penduduk yang semakin tinggi memberikan tekanan yang cukup besar terhadap lingkungan. Dimana populasi yang berkembang pesat dapat membawa kondisi hidup sengsara, kekurangan gizi, dan terserangnya wabah penyakit pada masyarakat.

Hal ini dibuktikan dengan data dari BPLHD DKI Jakarta tahun 2014, dinyatakan bahwa produksi sampah berbanding lurus dengan perkembangan dan pertambahan jumlah penduduk, yakni tahun 2013 dengan jumlah penduduk 9.969.948 jiwa, diperkirakan timbulan sampah per hari sebanyak 2.994,34 $\mathrm{m}^{3} /$ hari. Sedangkan pada 2014 dengan jumlah penduduk sebanyak 10.075.310 jiwa, perkiraan timbulan sampai mencapai $6.513,85 \mathrm{~m}^{3} /$ hari. Penyumbang 
sampah terbesar di Ibukota Jakartainiberasal dari sampah rumah tangga yaitu sebesar52,7\% (BPLHD Provinsi DKI Jakarta, 2014). Berdasarkan hal tersebut, secara signifikan perilaku manusia yang maladaptif memberikan kontribusi besar terhadap kondisi lingkungan global. Jika tidak segera diatasi dengan tepat, hal ini akan berdampak besar pada banyak hal sebagai contoh dalam segi kesehatan fisik maupun psikologis, seperti diare, flu akibat kondisi lingkungan yang kumuh, kanker karena terpapar polusi dari berbagai bahan kimia (Corvalan, Kjellstrom \& Smith, 1999), gangguan emosional, stress, dan bahkan kelelahan mental akibat buruknya kualitas lingkungan.

Untuk mencegah dan meminimalisir dampak buruk yang dapat terjadi, perlu adanya kepedulian terhadap lingkungan yang dimunculkan lewat perubahan perilaku yang relevan (Midden, Kaiser \& MsCalley, 2007). Dalam hal ini seperti kegiatan daur ulang sampah oleh masyarakat yang sudah dilakukan di beberapa daerah di antaranya Jakarta, Bandung, dan Surabaya. Salah satu keberhasilan kegiatan daur ulang sampah anorganik dan komposting dilakukan di Kampung Banjarsari, Jakarta Selatan, mampu menurunkan volume sampah yang biasanya dibuang ke tempat pembuangan sampah akhir hingga 50\% (Tanjung, 2008).

Dalam beberapa dekade terakhir, para peneliti telah menggunakan berbagai istilah untuk menggambarkan perilaku ini. Dalam Larson, Stedman, Cooper dan Decker (2015) disebutkan dengan istilah "perilaku pro- lingkungan" (Bamberg \& Moser, 2007; Steg, Bolderdijk, Keizer, \& Perlaviciute, 2014), "responsible environmental behaviors" (Cottrell, 2003; Vaske \& Kobrin, 2001), "perilaku ekologi" (Gray, Borden, \& Weigel, 1985; Kasier, 1998), "perilaku konservasi" (Gosling \& Williams, 2010; Kaiser, Hubner, \& Bogner, 2005), "environmentally supportive behaviors" (Huddart-Kennedy, Beckley, McFarlane, \& Nadeau, 2009), dan "environmentally significant behaviors" (Stern, 2000). Walaupun banyak istilah yang sudah dipakai, namun semua istilah tersebut memiliki makna dan tujuan yang sama.

Berdasarkan istilah-istilah yang telah digunakan tersebut, dalam penelitian ini peneliti menggunakan istilah perilaku pro- lingkungan. Perilaku prolingkungan adalah perilaku yang dilakukan untuk melindungi, memperbaiki serta meminimalisir dampak negatif dari aktivitas manusia terhadap lingkungan.

Dalam studi terdahulu ditemukan bahwa salah satu cara dalam meningkatkan partisipasi masyarakat dalam berperilaku pro- lingkungan adalah dengan memperhatikan kualitas dan ketersediaan fasilitas pelayanan di lingkungan yang ada. Seperti contoh yang seringkali terjadi dalam kehidupan sehari- hari, tidak adanya ketersediaan akses recycle barang-barang bekas akan membuat masyarakat lebih memilih untuk membuang atau bahkan membakar sampah tersebut dan menimbulkan polusi udara di sekitar (Kennedy, Beckley, McFarlane \& Nadeu, 2009).

Puspawati dan Besral (2008) menyebutkan bahwa salah satu upaya yang dapat dilakukan adalah mengurangi sampah dari sumbernya dengan memberdayakan lingkungan terdekat dan terkecil, yakni masyarakat di tingkat RT/RW, kelurahan serta kecamatan untuk mengelola sampah sendiri. Partisipasi masyarakat ini dikenal dengan program "pengelolaan sampah 
berbasis masyarakat", yang saat ini telah dilakukan di beberapa negara antara lain Thailand, India, Nepal, termasuk pula Indonesia, yang dalam hal ini menjadi salah satu prediktor dalam penelitian ini, yaitu kebijakan intervensi.

Berdasarkan hal itu, di era yang serius mengenai permasalahan lingkungan dan berpotensi terjadinya bencana alam ini, penting bagi kita meningkatkan perilaku pro- lingkungan pada masyarakat (Turaga, Howarth \& Borsuk, 2010). Dengan meningkatkan perilaku pro-lingkungan masyarakat di setiap daerah, diharapkan dapat menurunkan kemungkinan permasalahan lingkungan yang terjadi di masa yang akan datang.

Berdasarkan latar belakang yang telah dipaparkan, peneliti tertarik untuk melakukan penelitian lebih lanjut yang berkaitan dengan kebijakan intervensi, sikap terhadap perilaku pro-lingkungan, norma subjektif, perceived behavior control, environmental knowledge, faktor lingkungan fisik, jenis kelamin dan usia terhadap perilaku pro-lingkungan di daerah yang sudah ditetapkan kebijakan intervensi dan daerah yang belum diberikan kebijakan intervensi "pengelolaan sampah berbasis masyarakat" di Depok dan Tangerang Selatan. Sehingga peneliti memutuskan untuk memberi judul "Pengaruh kebijakan intervensi, faktor personal, dan faktor lingkungan fisik terhadap perilaku pro- lingkungan".

\section{METODE PENELITIAN}

\section{Populasi, sampel dan teknik pengambilan sampel}

Populasi dalam penelitian ini adalah masyarakat yang bertempat tinggal di Depok dan Tangerang Selatan yang telah mengikuti kebijakan intervensi "Pengelolaan Sampah Berbasis Masyarakat" oleh Bank Sampah Melati Bersih yaitu di Perumahan Villa Pamulang Indah RW 17 dan daerah Kedaung Ciputat RW 03 dan daerah yang belum mengikuti kebijakan intervensi di Perumahan Villa Pamulang Indah RW 11. Sampel penelitan sebanyak 201 orang dengan rentang usia 17-70 tahun.

Teknik sampling pada penelitian ini bersifat non probability sampling yaitu teknik pengambilan sampel secara sengaja sesuai dengan persyaratan sampel atau kriteria yang telah ditentukan. Dimana peluang terpilihnya setiap responden anggota populasi tidak dapat dihitung.

\section{Instrumen Penelitian}

Terdapat lima alat ukur yang digunakan dalam penelitian ini,yaitu:

\section{Alat ukur perilaku pro-lingkungan}

Perilaku pro-lingkungan diukur dengan menggunakan skala yang penulis susun sendiri berdasarkan dimensi alat ukur yang dikembangkan oleh Kaiser dan Wilson (2004) dalam General Ecological Behavior Scale (GEBS). Skala perilaku prolingkungan ini terdiri dari 36 butir item dengan 6 dimensi, tiap-tiap item berisi respon "ya" dan "tidak"(dikotomi).

2. Alat ukur sikap terhadap perilaku pro- lingkungan

Untuk mengukur sikap terhadap perilaku pro-lingkungan penulis mengadaptasi alat ukur New Ecological Paradigm (NEP) Revised yang dikembangkan oleh Dunlap, Liere, Mertig, dan Jones (2000). NEP Revised terdiri dari 5 indikator yaitu: 
balance of nature, ecocrisis, anti exemptionalism, limits to growth dan antianthtopocentricism dan masing-masing indikator tersebut terdiri dari 3 item. Respon jawaban untuk item ini menggunakan format skala likert 4 poin, mulai dari 1 (sangat tidak setuju) sampai 4 (sangat setuju).

\section{Alat ukur norma subjektif}

Norma subjektif diukur dengan menggunakan kuesioner yang disusun oleh penulis sendiri menggunakan komponen yang dikemukakan oleh Ajzen (1985). Respon jawaban untuk skala ini menggunakan skala likert dengan rentangan 1 (tidak pernah) sampai 4 (selalu).

4. Alat ukur perceived behavioralcontrol (PBC)

Perceived behavioral control (PBC) diukur dengan menggunakan kuesioner yang disusun oleh penulis dengan menggunakan aspek yang dikemukakan oleh Ajzen (2005). Kuesioner PBC ini menggunakan skala likert.

\section{Alat ukur environmental knowledge}

Environmental knowledge diukur menggunakan skala yang dikonstruk sendiri oleh penulis berdasarkan teori yang dikembangkan oleh Frick, Kaiser dan Wilson (2004). Alat ukur ini terdiri dari 9 item untuk dimensi system knowledge dengan dua respon jawaban dikotomi yaitu "ya" dan "tidak". Untuk dimensi action related knowledge terdiri dari 8 item dengan 3 respon jawaban, "banyak mengetahui", "cukup mengetahui", dan "tidak mengetahui sama sekali".

Sedangkan dimensi knowledge effectiveness terdiri dari 6 item masing- masing item menggunakan format pilihan ganda yang terdiri dari empat pilihan jawaban. Pada soal knowledge effectiveness ini hanya terdapat satu jawaban saja. Jawaban benar diberi skor 1 dan jawaban salah diberi skor 0 .

\section{Alat ukur faktor lingkungan fisik}

Faktor lingkungan fisik diukur dengan menggunakan kuesioner yang disusun oleh penulis sendiri. Skala ini terdiri dari dua dimensi yaitu faktor lingkungan fisik keluarga dan faktor lingkungan fisik masyarakat, masing-masing dimensi terdiri dari tiga indikator yang telah ditentukan, yaitu lingkungan sehat, bersih, dan hijau. Skala faktor lingkungan fisik ini menggunakan respon jawaban dikotomi yaitu "ya" dan"tidak".

\section{HASIL PENELITIAN}

\section{Analisa Deskriptif}

Total sampel dalam penelitian ini berjumlah 201 orang yang merupakan masyarakat yang bertempat tinggal di Depok dan Tangerang Selatan yang telah mengikuti program kebijakan intervensi "Pengelolaan Sampah Berbasis Masyarakat oleh Bank Sampah Melatih Bersih" dan daerah yang belum diterapkan kebijakan intervensi. Berikut adalah gambaran subjek dalam penelitian ini. 
Tabel 1

\begin{tabular}{ll}
\hline Data demografi & $\sum \boldsymbol{n}=\mathbf{2 6 6}$ \\
\hline $\begin{array}{l}\text { Jenis kelamin } \\
\text { Perempuan }\end{array}$ & $143(71 \%)$ \\
Laki-laki & $58(29 \%)$ \\
Tingkat pendidikan & \\
SD & $5(2 \%)$ \\
SMP & $16(8 \%)$ \\
SMA & $96(48 \%)$ \\
S1/S2/S3 & $84(42 \%)$ \\
Kelompok kebijakan intervensi & \\
Kebijakan penuh & $105(52 \%)$ \\
Kebijakan belum penuh & $50(25 \%)$ \\
Tidak ada kebijakanintervensi & $46(23 \%)$ \\
\hline
\end{tabular}

\section{Hasil Uji Hipotesis}

\section{Tabel 2}

Analisis regresi

\begin{tabular}{lcccc}
\hline Model & $\mathbf{R}$ & $\mathbf{R}^{2}$ & Adjusted $_{\mathbf{R}}{ }^{2}$ & Std. Error of the Estimate \\
\hline 1 & $0.634^{\mathrm{b}}$ & 0.401 & 0.356 & 6.87430 \\
\hline
\end{tabular}

Berdasarkan tabel 4.8 dapat dilihat bahwa perolehan $\mathrm{R}^{2}$ sebesar 0.401 atau40.1\%. Artinya proporsi varians dari perilaku pro- lingkungan yang dijelaskan oleh sikap terhadap perilaku pro-lingkungan, norma subjektif, perceived behavior control (PBC), system knowledge. action related knowledge, knowledge effectiveness, faktor lingkungan keluarga, faktor lingkungan masyarakat, kebijakan intervensi, jenis kelamin, usia dan interaksi antara kebijakan intervensi dan action related knowledge sebagai independent variable adalah sebesar $40.1 \%$, sedangkan $60.9 \%$ lainnya dipengaruhi oleh variabel lain di luar penelitian ini.

\section{Tabel 3}

Anova pengaruh keseluruhan IV terhadap DV

\begin{tabular}{lccccc}
\hline \multicolumn{1}{c}{ Model } & Sum of Squares & df & Mean Square & F & Sig. \\
Regression & 5893,835 & 14 & 420,988 & 8,909 &, $000^{2}$ \\
Residual & 8789,618 & 186 & 47,256 & & \\
Total & 14683,453 & & & & \\
\hline
\end{tabular}

Ada pun hasil uji F dapat dilihat pada tabel 4.5 Berdasarkan tabel 4.5, dapat diketahui bahwa nilai $\mathrm{p}$ (probability) pada kolom paling kanan sebesar 0.000 . nilai $\mathrm{P}<0.05$, maka hipotesis nihil yang menyatakan "Tidak ada pengaruh yang signifikan dari sikap terhadap perilaku pro-lingkungan, norma subjektif, perceived behavior control (PBC), system knowledge. action related knowledge, knowledge effectiveness, faktor lingkungan keluarga, faktor lingkungan masyarakat, kebijakan intervensi, jenis kelamin, usia dan interaksi antara kebijakan intervensi dan action 
related knowledge terhadap perilaku pro-lingkungan "ditolak". Artinya ada pengaruh yang signifikan dari sikap terhadap perilaku pro-lingkungan, norma subjektif, perceived behavior control (PBC), system knowledge, action related knowledge, knowledge effectiveness, faktor lingkungan keluarga, faktor lingkungan masyarakat, kebijakan intervensi, jenis kelamin, usia dan interaksi antara kebijakan intervensi dan action related knowledge terhadap perilaku pro-lingkungan.

\section{Tabel 4}

Koefisien Regresi

\begin{tabular}{lcccr}
\hline Model & Standardized Coefficients & Unstandardized Coef & \multicolumn{1}{c}{ t } \\
\hline (Constant) & B & S.E & Beta & \\
KI1 & 3.590 & 9.505 & - & .378 \\
KI2 & 18.758 & 6.833 & 1.096 & 2.745 \\
Sikap & .706 & 8.220 & .035 & .086 \\
Norma Subjektif & -.114 & .061 & -.119 & -1.857 \\
PBC & .310 & .070 & .314 & 4.456 \\
System Knowledge & .139 & .068 & .135 & 2.048 \\
Action Related Knowledge & .230 & .072 & .209 & 3.178 \\
Knowledge Effectivenes & .094 & .110 & .096 & .850 \\
Lingkungan Fisik Keluarga & -.056 & .080 & -.044 & -.693 \\
Lingkungan Fisik Masyarakat & .157 & .066 & .148 & 2.355 \\
Jenis Kelamin & -.023 & .084 & -.020 & -.279 \\
Usia & -.445 & 1.148 & -.024 & -.388 \\
KI1XARK & .142 & .045 & .192 & 3.154 \\
KI2XARK & -.289 & .134 & -.864 & -2.157 \\
& .174 & .160 & .434 & 1.083 \\
\hline
\end{tabular}

Berdasarkan tabel 4 dihasilkan persamaan regresi sebagai berikut:

Perilaku pro lingkungan $=3.590+18.758(\mathrm{KI} 1)^{*}+0.706(\mathrm{KI} 2)^{*}-0.114($ sikap$)$ +0.310 (norma subjektif)* $+0.139(\mathrm{PBC})^{*}+0.230$ (system knowledge) ${ }^{*}+0.094$ (action related knowledge) 0.056 (knowledge effectiveness) +0.157 (faktor lingkungan fisik keluarga) - 0.023 (faktor lingkungan fisikmasyarakat) -0.445 (jeniskelamin) +0.142 (usia)* - 0.289 (interaksi adanya kebijakan intervensi penuh berbanding dengan tidak ada kebijakan intervensi dan action related knowledge) ${ }^{*}+0.174$ (interaksi adanya kebijakan intervensi yang belum penuh berbanding dengan tidak ada kebijakan intervensi dan action related knowledge).

\section{Proporsi Varians}

Untuk proporsi varians dari masing-masing independent variable terhadap perilaku pro- lingkungan terdapat tujuh variabel yang secara signifikan memberikan sumbangan terhadap varians perilaku pro-lingkungan, yaitu norma subjektif, $\mathrm{PBC}$, system knowledge, faktor lingkungan keluarga, kebijakan intervensi, usia dan interaksi kebijakan intervensi dan action related knowledge.

1. Variabel kebijakan intervensi memberikan sumbangan sebesar $11.3 \%$ terhadap varians perilaku pro- lingkungan. Sumbangan tersebut signifikan 
dengan nilai $\mathrm{P}=0.000<0.05$ (significant).

2. Variabel sikap terhadap perilaku pro- lingkungan memberikan sumbangan sebesar $0 \%$ terhadap varians perilaku pro-lingkungan. Sumbangan tersebut tidak signifikan dengan nilai $\mathrm{P}=1.000>0.05$ (nonsignificant).

3. Variabel norma subjektif memberikan sumbangan sebesar $14.8 \%$ terhadap varians perilaku pro-lingkungan. Sumbangan tersebut signifikan dengan nilai $\mathrm{P}=0.000<0.05$ (significant).

4. Variabel perceived behavior control (PBC) memberikan sumbangan sebesar $2.5 \%$ terhadap varians perilaku pro- lingkungan. Sumbangan tersebut tidak signifikan dengan nilai $\mathrm{P}=0.010<0.05$ (significant).

5. Variabel system knowledge memberikan sumbangan sebesar $2.9 \%$ terhadap varians perilaku pro-lingkungan. Sumbangan tersebut signifikan dengan nilai $\mathrm{P}=0.005<0.05$ (significant).

6. Variabel action related knowledge memberikan sumbangan sebesar $0.1 \%$ terhadap varians perilaku pro- lingkungan. Sumbangan tersebut tidak signifikan dengan nilai $\mathrm{P}=0.585>0.05$ (nonsignificant).

7. Variabel knowledge effectiveness memberikan sumbangan sebesar $0.2 \%$ terhadap varians perilaku pro- lingkungan. Sumbangan tersebut tidak signifikan dengan nilai nilai $\mathrm{P}=0.459>0.05$ (nonsignificant).

8. Variabel faktor lingkungan fisik keluarga memberikan sumbangan sebesar $1,5 \%$ terhadap varians perilaku pro- lingkungan. Sumbangan tersebut signifikan dengan nilai $\mathrm{P}=0.039<0.05$ (significant).

9. Variabel faktor lingkungan fisik masyarakat memberikan sumbangan sebesar $0 \%$ terhadap varians perilaku pro-lingkungan. Sumbangan tersebut signifikan dengan nilai $\mathrm{P}=0.723>0.05$ (nonsignificant).

10. Variabel jenis kelamin memberikan sumbangan sebesar $0 \%$ terhadap varians perilaku pro-lingkungan. Sumbangan tersebut tidak signifikan dengan nilai $\mathrm{P}=0.985>0.05$ (nonsignificant).

11. Variabel usia memberikan sumbangan sebesar $3.2 \%$ terhadap varians perilaku pro-lingkungan. Sumbangan tersebut signifikan dengan nilai $\mathrm{P}=0.002<0.05$ (significant).

12. Variabel interaksi kebijakan intervensi dan action related knowledge memberikan sumbangan sebesar $3,7 \%$ terhadap varians perilaku prolingkungan. Sumbangan tersebut signifikan dengan nilai $\mathrm{P}=0.000<0.05$ (significant).

\section{KESIMPULAN, DISKUSI, DAN SARAN}

\section{Kesimpulan dan Diskusi}

Berdasarkan hasil analisis uji multiple regression, maka dapat disimpulkan bahwa terdapat pengaruh yang signifikan dari sikap terhadap perilaku pro-lingkungan, norma subjektif, perceived behavior control (PBC), system knowledge, action related knowledge, knowledge effectiveness, faktor lingkungan keluarga, faktor lingkungan masyarakat, kebijakan intervensi, jenis kelamin, usia dan interaksi antara kebijakan intervensi dan action related knowledge terhadap perilaku pro-lingkungan, yakni sebesar $40.1 \%$. 
Berdasarkan hasil uji hipotesis yang telah dilakukan, terdapat tujuh variabel yang memiliki pengaruh yang signifikan terhadap perilaku pro-lingkungan antara lain norma subjektif, perceived behavior control (PBC), system knowledge, faktor lingkungan keluarga, kebijakan intervensi dan usia berpengaruh signifikan secara positif sedangkan untuk interaksi antara kebijakan intervensi dan action related knowledge berpengaruh secara negatif signifikan.

Variabel pertama yang signifikan mempengaruhi perilaku pro-lingkungan dalam penelitian ini adalah kebijakan intervensi "program pengelolaan sampah berbasis masyarakat". Variabel kebijakan intervensi ini dibagi menjadi tiga, yaitu kelompok dengan kebijakan intervensi penuh (adanya bank sampah dan kegiatan komposting), kebijakan intervensi belum penuh (pengadaan bank sampah saja) dan tidak ada kebijakan intervensi, di mana kelompok tidak ada kebijakan intervensi yang dijadikan variabel kontrol.

Hasil penelitian ditemukan bahwa variabel KI1 (kelompok kebijakan intervensi penuh dibandingkan dengan tidak ada kebijakan intervensi) dan variabel KI2 (adanya kebijakan intervensi namun belum penuh dibandingkan dengan tidak ada kebijakan intervensi) memiliki pengaruh yang signifikan terhadap perilaku pro-lingkungan.

Hal tersebut menunjukkan bahwa adanya kebijakan intervensi dapat mempengaruhi perilaku pro-lingkungan individu, daripada daerah kelompok masyarakat yang belum ada kebijakan intervensi sama sekali. Sehingga dapat disimpulkan bahwa kebijakan intervensi yang telah diterapkan sudah efektif dalam mempengaruhi perilaku masyarakat untuk lebih peduli terhadap isu dankondisi lingkungan saat ini. Hal ini sesuai dengan hasil penelitian oleh Kua dan Wong (2012) menemukan bahwa program intervensi dapat menjadi salah satu strategi dalam menurunkan konsumsi energi rumah tangga diSingapura.

Selanjutnya, variabel norma subjektif terbukti memiliki pengaruh yang signifikan terhadap perilaku pro-lingkungan. Variabel ini berpengaruh positif dan signifikan terhadap perilaku pro-lingkungan. Hasil penelitian ini sejalan denganpenelitian yang dilakukan oleh Fielding, Racheldan Winnifred (2008), menyatakan bahwa individu yang memiliki keyakinan normatif yang tinggi berkaitan erat dengan munculnya perilaku pro-lingkungan. Selain itu hasil studi Davis, Le, Coy, Rickert, Regan dan Ridgeway (2015) menyatakan bahwa individu akan lebih berkomitmen terhadap lingkungan sejauh mereka yakin akan nilai- nilai pro-lingkungan yang diyakini oleh rekan-rekan terdekatnya.

Selanjutnya, variabel perceived behavior control (PBC) terbukti memiliki pengaruh yang signifikan terhadap perilaku pro-lingkungan. Variabel ini berpengaruh secara positif dan signifikan. Hal ini sejalan dengan penelitian Klockner (2013) serta Groot dan Steg (2007) yang menyatakan bahwa individu yang memiliki perceived behavior control yang tinggi maka akan meningkatkan kemungkinan individu tersebut untuk berperilaku pro-lingkungan.

Perceived behavior control adalah persepsi individu mengenai kemudahan dan adanya kesempatan untuk melakukan perilaku pro-lingkungan. Sehingga ketika individu memiliki persepsi bahwa dirinya mampu dan yakin bahwa kesempatan yang ada dapat memfasilitasi perilakunya, maka akan mendorong individu tersebut untuk berperilaku pro-lingkungan. Temuan penting dari studi perceived 
behavioral control ini ialah perlunya menciptakan kondisi yang dapat memfasilitasi perilaku pro-lingkungan di lingkungan masyarakat dan menghilangkan kondisi yang berpotensi menjadi hambatan dalam berperilaku pro-lingkungan. Contohnya, dengan melakukan penyediaan tempat sampah di lokasi strategis di sekitar lingkungan tempat tinggal, atau dengan diadakannya kegiatan gotong royong setiap minggu yang disertai dengan penyuluhan singkat mengenai lingkungan oleh pihak setempat.

Selanjutnya berdasarkan variabel environmental knowledge yang terdiri dari tiga dimensi yaitu system knowledge, action related knowledge dan knowledge effectiveness, terdapat satu jenis pengetahuan lingkungan yang secara signifikan memprediksi perilaku pro-lingkungan yaitu system knowledge. Nilai koefisien yang positif dari system knowledge dapat diartikan bahwa semakin banyak informasi mengenai masalah lingkungan dan bagaimana masalah lingkungan tersebut dapat terjadi maka semakin besar kemungkinan seseorang melakukan perilaku prolingkungan. Hal tersebut didukung oleh temuan Kaiser dan Fuhrer (2003) yang menemukan sebesar $(\mathrm{r}=0.54)$ varian perilaku pro-lingkungan dijelaskan oleh system knowledge. Dalam temuan lainnya, Gardner dan Stern (dalam Kaiser \& Fuhrer, 2003) menyatakan bahwa pengetahuan dapat membantu seseorang menghindari kesalahan informasi. Dengan adanya pengetahuan dapat membuat seseorang lebih sadar akan keadaan lingkungan sekitarnya. Individu yang memiliki pengetahuan yang memadai mengenai permasalahan lingkungan saat ini akan meningkatkan kesadarannya terhadap lingkungan, sehingga hal ini dapat membuatnya lebih termotivasi untuk peduli terhadap lingkungan (Molina \& Sainz, 2013).

Selanjutnya berdasarkan variabel faktor lingkungan fisik yang terdiri dari dua dimensi yaitu faktor lingkungan fisik keluarga dan faktor lingkungan fisik masyarakat, hasil penelitian menemukan bahwa ada pengaruh yang signifikan faktor lingkungan fisik keluarga terhadap perilaku pro-lingkungan. Faktor lingkungan fisik keluarga pada penelitian ini adalah variabel background keadaan lingkungan subjek secara mikro meliputi bagaimana keadaan rumah dan sekitarnya, seperti toilet, kamar tidur, ruang tamu, halaman dan sebagainnya. Variabel ini berpengaruh secara positif dan signifikan terhadap perilaku prolingkungan. Individu yang memiliki lingkungan rumah dan keluarga yang sehat, bersih, dan hijau, maka akan memotivasi individu untuk terus peduli dan turut berpartisipasi dalam meningkatkan kualitas lingkungan. Seperti hasil temuan Fliegenschnee dan Schelakovsky (dalam Blok, Reante, Oldrich \& Ron, 2014) yang menyimpulkan bahwa situasi lingkungan sekitar memainkan peran penting dalam menentukan perilaku pro- lingkungan individu.

Selanjutnya variabel usia terbukti memiliki pengaruh positif dan signifikan terhadap perilaku pro-lingkungan. Hal ini menunjukkan bahwa semakin tua usia individu semakin tinggi kecenderungannya dalam berperilaku pro-lingkungan. Hasil penelitian ini sejalan dengan penelitian yang dilakukan oleh Wiernik dan Deniz (2013) serta Gifford (2014), yang memaparkan bahwa perbedaan individu memiliki pengaruh yang signifikan terhadap perilaku pro- lingkungan, dimana individu yang lebih tua ditemukan lebih cenderung berperilaku pro- lingkungan (seperti mereka lebih cenderung meminimalisir dan menghindari barang sekali 
pakai, menggunakan kembali barang yang masih layak pakai, dan daur ulang) daripada orang-orang muda. Sehingga perlu adanya dorongan aktif kepada kaum muda mengenai usaha pencegahan tentang bahaya yang dapat terjadi di lingkungan sekitar. Sebuah penelitian mengenai environmental motives menemukan bahwa dibandingkan dengan orang-orang pada usia tua, penerapan intervensi mengenai masalah lingkungan pada orang yang berusia muda tidak cukup hanya dengan dibuatnya aturan dan norma- norma sosial, namun perlunya intervensi secara individual, dengan pendekatan reward dan pujian (Wiernik \& Ones,2013).

Dalam penelitian ini, penulis menambahkan analisis statistik berupa interaksi antara kebijakan intervensi dan action related knowledge. Analisis interaksi ini digunakan untuk melihat pengaruh hubungan antara variabel kebijakan intervensi dan action related knowledge terhadap perilaku pro-lingkungan. Hal ini seperti yang dijelaskan oleh Frick, Kaiser dan Wilson (2004) bahwa peran variabel pengetahuan lingkungan dalam hal ini adalah action related knowledge, akan lebih mudah untuk dipahami dalam memprediksi perilaku pro-lingkungan jika dijadikan variabel moderator. Hal ini karena dalam banyak penelitian ditemukan bahwa pengetahuan lingkungan hanya memiliki pengaruh yang tidak langsung terhadap perilaku pro-lingkungan

Hasil regresi dari interaksi tersebut ternyata negatif dan signifikan pada kelompok dengan kebijakan intervensi penuh berbanding dengan tidak ada kebijakan intervensi dan action related knowledge terhadap perilaku pro-lingkungan. Hal ini dapat diinterpretasikan bahwa ada perbedaan yang signifikan antara perilaku pro- lingkungan di tempat yang belum ada kebijakan intervensi dengan tempat yang sudah ada kebijakan intervensi penuh, tetapi ini pun bergantung pada action related knowledge. Koefisien regresi yang dihasilkan negatif memiliki arti bahwa individu yang memiliki action related knowledge yang rendah, justru perilaku prolingkungannya tinggi jika diterapkan pada kelompok kebijakan intervesi penuh (KI1) namun pada individu yang memiliki action related knowledge sudah tinggi kebijakan intervesi penuh (KI1) ini tidak berpengaruh dalam memprediksi perilaku pro-lingkungan. Sehingga dapat dikatakan bahwa kebijakan intervensi oleh bank sampah melati bersih di Villa Pamulang sudah efektif dan berhasil dalam mengubah perilaku masyarakat. Hal ini khususnya jika yang diterapkan adalah kebijakan penuh (adanya bank sampah dan kegiatan komposting) dan diberikan kepada masyarakat dengan tingkat pengetahuan yang rendah, sehingga mereka menjadi lebih sadar dan peduli terhadap lingkungan.

Dalam penelitian ini terdapat beberapa variabel yang terbukti tidak memiliki pengaruh yang signifikan terhadap perilaku pro-lingkungan. Hal ini terkadang menjadi pertentangan dengan penelitian terdahulu. Adapun variabel yang terbukti tidak memiliki pengaruh terhadap perikaku pro-lingkungan antara lain sikap terhadap perilaku pro-lingkungan, action related knowledge, knowledge effectiveness, faktor lingkungan fisik masyarakat dan jenis kelamin.

Sikap terhadap perilaku pro- lingkungan tidak terbukti memiliki pengaruh yang signifikan terhadap perilaku pro- lingkungan. Hal ini bertentangan dengan penelitian terdahulu yang dilakukan oleh Niaura (2013) dan Bamberg dan Moser (2007) yang menyatakan bahwa individu yang memiliki sikap terhadap perilaku pro- lingkungan yang positif akan meningkatkan kecenderungannya dalam 
berperilaku pro- lingkungan. Namun mengenai hasil penelitian ini sesuai dengan pemaparan Ajzen dan Fishbein (2005) bahwa adanya kesenjangan antara sikap dan perilaku, dalam banyak penelitian ditemukan bahwa sikap adalah prediktor yang lemah dalam memprediksi perilaku aktual. Hasil penelitian oleh Vermeir dan Verbeke (dalam Molina \& Sainz, 2013) juga menyatakan bahwa sikap adalah prediktor yang kurang baik dalam memprediksi perilaku pro-lingkungan, dan tidak memiliki pengaruh yang signifikan dalam mempengaruhi perilaku prolingkungan. Selain itu, penulis juga berasumsi bahwa terjadinya hal tersebut salah satunya karena kurang ketelitian dari penulis dalam pemilihan dan pengadaptasian skala alat ukur, sehingga jika dilihat secara validitas kontennya kurang dapat mengukur apa yang ingin diukur, yaitu sikap terhadap perilaku prolingkungan.

Selanjutnya dua dimensi lainnya dari variabel pengetahuan lingkungan yaitu action related knowledge dan knowledge effectiveness tidak terbukti memiliki pengaruh yang signifikan terhadap perilaku pro-lingkungan. Hal ini bertentangan dengan penelitian Frick, Kaiser dan Wilson (2004) yang menyatakan bahwa secara teoritis dan telah dibuktikan dalam suatu penelitian dengan 500 responden, dan ditemukan bahwa perilaku pro-lingkungan dipengaruhi secara langsung oleh action related knowledge dan knowledge effectiveness. Selain itu ditemukan bahwa system knowledge dapat memprediksi action related knowledge, dan action related knowledge dapat memprediksi knowledge effectiveness.

Namun dalam Frick, Kaiser dan Wilson (2004) menyebutkan bahwa beberapa penelitan mengenai pengetahuan lingkungan memang memperlihatkan hasil korelasi yang kecil, seperti yang ditemukan pada populasi di Swiss. Jika variabel pengetahuan lingkungan ini dijadikan variabel moderator dalam memprediksi perilaku pro-lingkungan, maka peran dari variabel pengetahuan lingkungan ini akan lebih mudah untuk dipahami. Selanjutnya variabel faktor lingkungan fisik masyarakat, pada penelitian ini adalah variabel background keadaan lingkungan subjek secara makro meliputi sekumpulan rumah individu sebagai tempat untuk melakukan aktivitas sosial antar masyarakat, seperti bagaimana keadaan tempat pembuangan sampah bersama, dan adanya ruang hijau terbuka disekitar. Variabel ini tidak terbukti memiliki pengaruh yang signifikan terhadap perilaku pro- lingkungan. Hal ini bertentangan dengan penelitian hasil temuan Fliegenschnee and Schelakovsky (dalam Blok, Reante, Oldrich \& Ron, 2014) yang menyimpulkan bahwa situasi lingkungan sekitar memainkan peran penting dalam menentukan perilaku pro- lingkungan individu. Namun penulis berasumsi bahwa adanya hukum sosial social loafing dalam kondisi seperti ini. Social loafing adalah berkurangnya usaha individu, ketika ia bekerja secara kolektif di dalam kelompok dibandingkan bekerja secara individual (APA Dictionary, 2012). Artinya bahwa lingkungan yang bersih, sehat dan hijau di sekitar tempat tinggal, begitupun sebaliknya, tidak memiliki dampak yang signifikan terhadap terbentuknya perilaku pro-lingkungan.

Variabel jenis kelamin tidak terbukti memiliki pengaruh yang signifikan terhadap perilaku pro-lingkungan. Penelitian ini sejalan dengan studi terdahulu yang dilakukan oleh Sanchez, Mosquera dan Lopez (2015) serta Song, Wan dan Li (2012), yang menyatakan bahwa perbedaan jenis kelamin (laki-laki atau 
perempuan) tidak dapat memprediksi perilaku pro-lingkungan dalam kehidupan sehari-hari.

\section{Saran}

Pada penelitian tentang perilaku pro-lingkungan kali ini sumbangan seluruh independent variable sebesar $40,1 \%$ sedangkan 59,9\% lannya dipengaruhi oleh variabel lain. Sehingga pada penelitian selanjutnya, penulis menyarakan untuk menganalisis faktor-faktor lain yang dapat mempengaruhi perilaku prolingkungan seperti belief, value, pengetahuan agama terkait lingkungan, dan sebagainya.

Disarankan untuk peneliti berikutnya untuk menguji model theory of planned behavior (TPB) dengan menambahkan variabel intensi. Hal ini dilakukan menggunakan model perhitungan statistik structural equation model (SEM) untuk memperoleh hasil yang lebih baik dan dapat mempertimbangkan variabel mediator tersebut. Selain itu dengan metode SEM juga dapat mempertimbangkan berbagai error yang terjadi dalam model.

Untuk penelitian selanjutnya disarankan untuk menggunakan sampel yang lebih banyak dan teknik sampling yang lebih sistematis. Diharapkan dapat memperoleh hasil penelitian yang lebih baik dan akurat, sehingga dapat memberikan gambaran kepada pemerintah dan institusi terkait dalam mencari solusi yang lebih efektif atas permasalahan lingkungan.

Dari hasil penelitian, diketahui bahwa pengetahuan lingkungan memberikan dampak yang signfikan terhadap perilaku pro-lingkungan. Oleh sebab itu, disarankan kepada individu dan pihak-pihak terkait untuk menambah informasi dan wawasan mengenai permasalahan yang terjadi serta bagaimana mempraktekkan gaya hidup yang pro-lingkungan dalam kehidupan sehari-hari.

\section{DAFTAR PUSTAKA}

Ajzen, I. (2005). Attitude, Personality and Behavior Second Edition. New York: Open Unversity Press.

Ajzen, I. (1985). From intentions to actions : a theory of planned behavior In J. Kuhl, Action Control, 11-39, Springer-Verlag BerlinHeideiberg.

American Psychological Association. (2015). APA Dictionary of Psychology Second Editon. Washington, DC. doi: 10.1037/14646-000

Badan Pengelola Lingkungan Hidup Daerah (BPLHD) Provinsi Daerah Khusus Ibukota Jakarta. (2014). Laporan Status Lingkungan Hidup Daerah Provinsi Daerah Khusus Ibukota Jakarta Tahun 2014. Di unduh pada tanggal 21 Januari 2016 pukul 23:29 dari bplhd.jakarta.go.id/

Bamberg, S., \& Moser, G. (2007). Twenty years after hines, hungerford, and tomera: a new meta-analysis of psycho- social determinants of proenvironmental behavior. Journal of Environmental Psychology, 27, 14-25. doi:10.1016/j.jenvp.2006.12.002

Blok, V., Renate W., Oldrich S. \& Ron K. (2014). Encouraging sustainability in the workplace: a survey on the pro- environmental behviour of unniversity employees. Journal of Cleaner Production. 1-12. doi.10.1016/j.jclepro.2014.07.063 
Corvalán, C., Kjellstrom, L., \& Smith, K. (1999). Health, environment and sustainable development: identifying links and indicators to promote action. Epidemiology, 10 (5), 656-660.

Davis, J.L., Le, B., Coy, A.E., Rickert, J., Regan, B., \& Ridgeway, K. (2015). Commitment to the environment: The role of subjective norms in college and community samples. Journal of Applied Social Psychology, 45, 568-583. doi: $10.1111 /$ jasp. 12320

Dunlap, Liere, Mertig \& Jones. (2000). Measuring endorsement of the new ecological paradigm: a revised NEP scale. Journal of Social Issues, 56 (3), 425-442.

Fielding, K.S, McDonald, R. \&Louis W.R. (2008). Theory of planned beahviour, identity and intentions to engage in environmental activism. Journal of Environmental Psychology, 28, 318-

325. doi:10.1016/j.jenvp.2008.03.003

Frick, J., Kaiser, F., \& Wilson, M. (2004). Environmental knowledge and conservation behavior: Exploring prevalence and structure in a representative sample. Personality and individual differences, 37, 1597-1613. doi: $10.1016 /$ j.paid.2004.02.015

Gifford, R. (2014). Environmental psychology matters. The annual Review of Psychology, 65, 541-579. doi:10.1146/annurev-psych-010213- 115048.

Groot, J.D., \& Steg, L. (2007). General belief and the theory of planned behavior: The role of environmental concerns in the TPB. Journal of Applied Social Psychology, 37 (8), 1817-1836.

Kaiser, F \& Fuhrer, U. (2003). Ecological behavior's dependency on different forms of knowledge. Applied psychology, 52 (4), 598-613.

Kaiser, F.G. \& Wilson, M. (2004). Goal- directed conservation beahvior: The specific composition of a general performance. Personality and Individual Differences, 36, 1531-1544. doi: 10.1016/j.paid.2003.06.003

Kennedy, E.H., Beckley, T.M., McFarlane, B.L., Nadeau, S., (2009). Why we don't walk the talk: Understanding the environmental values/behaviour gap in Canada. Human Ecology Review. 16(2), 151-160.

Klockner, C.A. (2013). A comprehensive model of the psychology of environmental behaviora meta analysis. Global Environmental Change, 23, 1028- 1038.doi:10.1016/j.gloenvcha.2013.05. 014

Kua, H.W., \& Wong, S.E. (2012). Lessons for intergrated household energy conservation policies from an intervention study in Singapore. Energy Policy, 47, 49-56. doi: 10.1016/j.enpol.2012.04.009

Larson, L.R., Stedman, R.C., Cooper, C.B., \& Decker., D.J. (2015). Understanding the multi dimensional structure of Pro- Environmental behavior. Journal of Environmental Psychology, 43,112-124, doi: 10.1016/j.jenvp.2015.06.004

Midden, C.J.H., Kaiser, F.G. \& McCalley, T. (2007). Technology's four roles in understanding individuals concervations of natural resources. Journal of Social Issues, 63 (1), 155-174

Molina, M .A.V., Fernandez-Sainz, A., Izagirre-Olaizola, J. (2013). Environmental Knowledge and Other Variables Affecting Pro- 
Environmental Behavior: Comparison of University Students from Emerging and Advanced Countries. Journal of Cleaner Production. doi: 10.1016/ j.jclepro.2013.05.015.

Niaura, A. (2013). Using the theory of planned behavior to investigate the determinants of environmental behavior among youth. Environmental Research, Engineering and Management, 1(63), 74-81.

Oskamp, S. (2000). Psychological Contributions to Achieving an Ecologically Sustainable Future for Humanity. Journal of Social Issues, 56 (3), 373-390.

Puspawati, C., \& Besral. (2008). Pengelolaan sampah berbasis masyarakat di kampng rajawati Jakarta Selatan. Jurnal Kesehatan Masyarakat Nasional, 3(1), 9-15.

Sanchez, M., Mosquera, N.L., \& Lopez, F.L. (2015). Improving proenvironmental behaviours in Spain. The role of attitude and sociodemographic and political factors. Journal of Envionmental Policy and Planning, 1-21. doi: 10.1080/1523908X.2015.1046983 Song,

Q.,Wan,Z., \& Li, J. (2012). Residents' behaviors, attitudes, and willingness to pay for recycling ewaste in Macau. Journal of Environmental Management, $106,8-16$.

Susandi, Armi, Indriani Herlianti, \& Mamad Tamamadin. (2008). Dampak Perubahan Iklim terhadapKetinggian Muka Laut di Wilayah Banjarmasin. Institut Teknologi Bandung. Di unduh tanggal 11 Februari 2016 dari http://armisusandi.com/articles/working_paper/8.pdf

Tanjung, Amrizal. (2008). Waste management program in Indonesia: Reduce, reuse, recycle program. Diunduh dari http://www2.gec.jp/gec/en/Activities/ecotown/FY2008/06amrizal.pdf

Turaga, R.M.R., Howarth, R.B. \& Borsuk, M.E (2010). Pro-environmental behavior: Rational choice meets moral motivation. Issue: Ecological Economics Reviews, 211-224.

Utama, Abraham. (2015). BNPB: Kebakaran Hutan 2015 Seluas 32 Wilayah DKI Jakarta. di akses pada tanggal 21 Januari 2016 pukul 20.00 dari http://www.cnnindonesia.com/nasional/20151030133801-2088437/bnpb-kebakaranhutan-2015-seluas-32-wilayah-dki-jakarta/

Wiernik, B.M. \& Ones. D.S. (2013), Age and environmental sustainability: A meta analysis. Journal of management psychology, Vol. 28 Iss 7/8 pp. 826-856. Doi. 10.1108/JMP-07-2013-0221. 
